\title{
Performans reproduksi induk babi yang di pelihara secara intensif di Kelurahan Kambajawa Kabupaten Sumba Timur
}

\section{Reproductive performance of the sows maintaned intensively in Kamba- jawa Distric, East Sumba Regency}

\author{
Alexander Kaka* \\ Program Studi Peternakan-Universitas Kristen Wira Wacana Sumba
}

Submitted : 18 August 2017, Accepted : 06 November 2017

\begin{abstract}
ABSTRAK: Penelitian ini bertujuan untuk mengetahui performans reproduksi induk babi yang dipelihara secara intensif di Kelurahan Kambajawa Kabupaten Sumba Timur. Penelitian dilaksanakan dari bulan Januari sampai dengan Maret 2017 dengan metode penelitian yang digunakan adalah survei dengan wawancara langsung terhadap 200 responden dan 196 induk babi sebagai sampel. Data dianalisis dengan pendekatan statistik deskriptif yang digambarkan pada tabel frekuensi dari setiap indikator atau dimensi. Adapun variabel yang diukur adalah waktu estrus, siklus estrus, litter size, jumlah sapihdan angka mortalitas. Berdasarkanhasil penelitian menunjukkan bahwa performans reproduksi ternak babi yang dipelihara secara intensif tergolong dalam kategori baik. Dengan demikian dapat disimpulkan bahwa performans reproduksi induk babi di Kelurahan Kambajawa yakni lama estrus 3,67 $\pm 1,28$ hari, siklus estrus $21,15 \pm 1,64$ hari, liter size $8,50 \pm 1,39$ ekor serta mortalitas $39,71 \%$.
\end{abstract}

Kata kunci: Babi, Intensif, Kinerja, Reproduksi,

ABSTRACT: The purpose of this research is to know the performance of sows reproduction intensively in Kambajawa sub-district, East Sumba regency. The study was conducted from January until March 2017 and this research is a survey method with a direct interview to 200 respondents as a population and 196 sows. The data were analyzed by descriptive statistic approach depicted on frequency table for each indicator or dimension. The measured variables were estrus time; estrus cycle; litter size; wean quantity; and mortality rate. Based on this study, it is known that the reproductive performance of the sows maintained intensively was categorized well. Thus, it can be concluded that the reproductive performance of sows in Kambajawa district that is, estrus duration $4.21 \pm 1.10$ days, estrus cycle $21.15 \pm 1.64$ days, litter size $8.50 \pm 1.39$ and $39.71 \%$ of mortality.

Keywords: Intensively, Performance, Reproduction, Sows

\section{PENDAHULUAN}

Pembangunan sub sektor peternakan pada prinsipnya untuk meningkatkan kesejahteraan petani peternak. Salah satu ternak potensial yang diusahakan/dipelihara di Sumba adalah ternak babi. Ternak babi mempunyai peranan penting untuk menopang ketahanan pangan dan sebagai pelengkap sosial budaya pada masyarakat
NTT, sehingga memiliki potensi yang cukup besar untuk dikembangkan.

Usaha beternak babi pada dasar mempunyai dua tujuan yaitu untuk memperoleh hasil produksi (daging dan nilai ekonomi bagi peternak yang mengusahakannya) serta dalam kepentingan sosial budaya masyarakat Sumba. Menurut (Kojo dkk, 2014; Sapanca et al, 2015), salah satu

*Corresponding author: alexanderkaka84@yahoo.com 
jenis ternak potong nonruminansia sebagai penyumbang protein yang telah diakui seluruh dunia adalah ternak babi. Selain itu, Menurut (Sihombing, 2006), tujuan pemeliharaan babi adalah untuk melestarikan tradisi dalam suatu keluarga, untuk memenuhi corak kehidupan desa dimana babi berperansebagai materi kebudayaan dalam berbagai upacara adat istiadat, dan untuk berpartisipasi aktif dalam pengadaan pangan nasional maupun internasional. Sedangkan Utomo dan Wahyuningsih, (2010); Seseray et al., (2012), melaporkan bahwa ternak babi adalah salah satu penghasil daging, pupuk organik dan biogas.

Dilihat dari peran ternak babi tersebut karena ternak babi memiliki keunggulan lain karena merupakan jenis ternak mamalia yang menghasilkan anak dalam jumlah banyak (polytocous). Sedangkan Sondang dan Siagian, (1999) ternak babi memiliki keunggulan sebagai penghasil daging untuk dikembangkan dalam rangka pemenuhan permintaan akan protein hewani. Ada beberapa keunggulan ternak babi yakni pertumbuhannya yang cepat, konversi pakan yang sangat baik dan mudah beradaptasi dengan lingkungan serta persentase karkasnya dapat mencapai $65 \%-80 \%$.

Salah satu tingginya, permintaan akan ternak babi di sumba karena penggunaan babi pada saat upacara adat maupun memenuhi kebutuhan peternak, baik untuk papan, pangan dan sandang. Meskipun demikian, peternakan secara umum di Sumba diternakan secara tradisional. Menurut (Ardana dan Putra, 2008, peternakan babi secara tradisional berpengaruh terhadap peningkatan produktivitas dari peternakan babi itu sendiri. Berdasarkan data BPS Sumba Timur dalam angka (2015) menunjukkan gambaran pertumbuhan ternak babi terjadi penurunan populasi sebesar $2,99 \%$. Ada indikasi beberapa factor penyebab turunnya populasi ternak antara lain beberapa jenis ternak terjangkit penyakit sehingga mengalami kematian, selain itu adanya mutasi ternak keluar daerah yang cukup besar. Menurut Sihombing, (2006), pemeliharaan ternak babi menghadapi beberapa kendala, salah satu diantaranya adalah masalah penyakit.

Indikasi lain adalah performans reproduksi ternak babi disumba timur tergolong rendah. Hal ini didukung beberapa laporan hasil penelitian bahwa produktivitas ternak babi masih belum optimal (Geisert dan Schmitt, 2002). Sedangkan penelitian Mege, et al., (2007), melaporkan bahwa selama kebuntingan pada babi terjadi kematian embrional mencapai 30-50\%.

Mortalitas anak babi selama asuhan induk dapat mencapai $72 \%$, sebagian besar terjadi pada minggu pertama kelahiran dan tertindih/terinjak induk sebagai penyebab utama (Aritonang dan Silalahi, 1999). Untuk mengatasi hal tersebut maka perlu diperhatikan manajemen reproduksi ternak babi. Hal ini mendukung pernyataan Pardosi (2004), faktor yang penting dalam beternak babi adalah liter size, bobot lahir, jumlah dan bobot anak yang disapih. Performans reproduksi merupakan salah satu yang harus dapat diperhatikan oleh peternak, dengan harapan dapat memperoleh jumlah anak atau litter size lebih banyak. Dari skalapeternakan rakyat performans reproduksi merupakan kendala yang banyak terjadi, karena keterbatasan peternak dalam pengetahuan dan penanganan ternak yang baik dalam memperhatikan litter size. Dengan demikian, dalam peningkatan populasi dan produksi ternak gambaran performans reproduksi ternak sangat diperlukan serta kurangnya informasi tentang produksi dan produktivitas ternak babi mendorong penelitian ini dilakukan dengan tujuan untuk mengetahui Performans reproduksi induk babi yang dipelihara secara intensif di 
Kelurahan Kambajawa Kabupaten Sumba Timur.

\section{MATERI DAN METODE}

Penelitian ini dilaksanakan di Kabupaten Sumba Timur, Keluruhan Kambajawa, yang berlangsung dari bulan JanuariMaret 2017. Dengan rincian sebagai berikut: satu bulan masa persiapan, satu bulan masa penelitian dan pengambilan data serta satu bulan tabulasi data dan penulisan hasil penelitian. Adapun materi yang digunakan dalam penelitian ini adalah induk babi yang dipelihara secara intensif sebanyak 196 ekor. Data penampilan reproduksi diambil dari hasil wawancara dengan pemilik peternakan dengan mengajukan kuisioner. Kriteria peternakan intensif yang diteliti adalah peternakan- peternakan yang memiliki induk babi dengan kriteria: 1-5 kali beranak. Dalam penelitian ini menggunakan populasi sebanyak 200 peternak yang ada di kelurahan tersebut. Sedangkan sampel yang digunakan dalam penelitian ini adalah teknik random sampling dimana setiap populasi mempunyai kesempatan yang sama untuk digunakan sebagai sampel. Penelitian ini melakukan pengumpulan data dengan beberapa tahapan antara lain: 1). Observasi. Tahap ini merupakan langkah awal yang dilakukan dalam menentukan lokasi penelitian. 2). Wawancara. Setelah melakukan tahap I maka dilakukan wawancara terhadap peternakan dengan menggunakan metode wawancara terstruktur dan tidak terstruktur. 3). Pengambilan data. Tahap ini dilakukan melalui pencatatan dan pengamatan terhadap variabel penelitian.

Untuk melengkapi dan membatasi data penelitian terhadap reproduksi ternak babi, maka ada dua jenis data yang digunakan dalam penelitian ini adalah: 1). Data primer. Data ini didapatkan saat survei dan wawancara di lapangan dengan menggunakan kuisioner. 2). Data Sekunder. Data ini bersumber dari literatur secara umum yang mendukung penelitian ini.

Untuk mengetahui perfomans reproduksi ternak maka dilakukan tabulasi data berupa: 1). Data kuantitatif yaitu data yang berbentuk angka yang diperoleh dari hasil kuisioner. 2. Data kualitatif yaitu data referensi yang diperoleh dari kajian informasi umum yang mendukung penelitian ini

\section{Jumlah sampel}

Adapun jumlah sampel diambil dengan menggunakan rumus slovin sehingga diperoleh jumlah sampel sebanyak 196 ekor. Untuk menentukan jumlah sampel maka dilakukan langkah-langkah sebagai berikut:

a. Pengamatan data performans reproduksi induk babi yang di memiliki peternak babi di Kelurahan Kambajawa.

b. Penentuan jumlah sampel penelitian mengikuti rumus dibawah ini:

$$
n=\frac{N}{1+N(e)^{2}}
$$

Ket :

n : Ukuran sampel

N : Jumlah Populasi (200)

$\mathrm{e}^{2}$ : prosentase pengambilan sampel yang masih diinginkan (1\%)

\section{Metode}

Metode dalam penelitian ini menggunakan analisis kuantitatif dengan pendekatan statistik deskriptiif. Analisis deskriptif ini berbentuk data yang diperoleh pada saat pengambilan sampel.

\section{Parameter penelitian}

Parameter dalam penelitian ini terdiri dari:

1. Lama estrus dan siklus estrus (\%): jumlah induk yang estrus danbersiklus 
estrus di bagi dengan total induk yang diteliti kemudian dikali dengan $100 \%$.

2. Liter size: jumlah anak yang lahir per induk kemudian diambil rataan anak babi dari semua induk.

3. umlah sapih: yakni jumlah anak yang disapih dibagi dengan total anak yang lahir dikali dengan $100 \%$

4. Angka Mortalitas (\%): jumlah anak babi yang mati sebelum disapih.

\section{HASIL DAN PEMBAHASAN \\ Karakteristik responden}

Data responden disajikan pada Tabel 1. Sebagian besar responden peternak babi di Kelurahan Kambajawa adalah lakilaki $(75 \%)$ dan perempuan $(25 \%)$ dengan umur berkisar antara 30-40 tahun (30\%), umur diatas 41-50 tahun (50\%) dan umur 51-60 tahun sebesar (20\%). Dengan pekerjaan pokok petani/peternak 52,5\%, PNS $25 \%$ dan wiraswasta $22,5 \%$. Tingkat pendidikan peternak hasil survei responden bervariasi dan yang tertinggi rata-rata merupakan lulusan SMA dengan angka $24 \%$, tidak tamat $22,5 \%$, perguruan tinggi $20 \%$, SMP $18 \%$ dan SD $15,5 \%$. Tingkat pendidikan formal yang ditempuh peternak berpengaruh pada pengelolaan ternaknya. Tingkat pendidikan sangat berpengaruh terhadap pengelolaan ternak yang dimiliki karena orang yang cenderung pendidikannya lebih baik dan mudah dalam menerima teknologi baru (Lestari, 2000).

Walaupun demikian pendidikan masyarakat yang cukup (tamatan SMA) memungkinkan untuk diberi informasi terkait performans reproduksi ternak. Hasil survei juga terlihat rata-rata para peternak sudah memulai usaha atau memelihara ternak babi dengan tingkat yang bervariasi namun mayoritas peternak sudah memulai usaha beternak babi lebih dari 5 tahun $(43,3$ $\%$ ), sedangkan 2-4 tahun mencapai 56,7\%.

Tabel 1. karakteristik responden

\begin{tabular}{clcc}
\hline No & \multicolumn{1}{c}{ Responden } & Persentase & Rata-rata Kepemilikan \\
\hline 1. & Laki-laki & $75 \%$ & 4 \\
2. & Perempuan & $25 \%$ & 2 \\
3. & Umur: & & \\
& 30-40 tahun & $30 \%$ & 5 \\
& 41-50 tahun & $50 \%$ & 1 \\
& 51-60 tahun & $20 \%$ & 2 \\
4. & Pendidikan: & & \\
& SD & $15,5 \%$ & 2 \\
& SMP & $18 \%$ & 1 \\
& SMA & $24 \%$. & 4 \\
& Perguruan Tinggi & $20 \%$ & 5 \\
& Tidak Tamat & $22,5 \%$ & 3 \\
Mata pencaharian: & & 5 \\
$\quad$ Petani/peternak & $52,5 \%$ & 2 \\
$\quad$ PNS & $25 \%$ & 3 \\
\hline
\end{tabular}

Pemahaman terhadap performans reproduksi adalah hal yang sangat penting dalam beternak babi untuk menentukan manajemen reproduksi sehingga populasi ternak dapat di tingkatkan. Hal yang penting juga pada tabel 1 adalah kecenderungan peternak babi di Kelurahan Kambajawa merupakan peternak dengan skala usaha 
kecil dimana terlihat dari jumlah kepemilikan ternak berkisar antara 1-5 ekor. Performans reproduksi ternak yang rendah sering terjadi pada peternakan dengan skala usaha kecil hal ini disebabkan peternakan skala kecil rendah dalam manajemen kontrol terhadap reproduksi, pakan kesehatan maupun manejemen pemeliharaan. Sedangkan peternakan dengan skala besar berdampak pada manajemen kontrol yang rutin secara teratur dan sistematis baik berbagai aspek manajemen ternak babi.

\section{Performans reproduksi induk babi}

Performans reproduksi merupakan salah satu indikator keberhasilan dari kinerja reproduksi ternak babi. Keterampilan dalam mendeteksi estrus dan proses mengawinkan babi menjadi kunci dalam keberhasilan terhadap produksi dan produktivitas ternak. Hasil penelitian terlihat bahwa sistem pemeliharan induk babi pada umumnya dilakukan secara intensif sehingga gambaran perfomans reproduksi diperoleh dalam kategori baik. Performans reproduksi merupakan gambaran umum keberhasilan suatu usaha dibidang peternakan. Hasil penelitian terhadap performans reproduksi ternak babi betina di Kelurahan Kambajawa terlihat pada tabel dibawah ini (Tabel 2)

Tabel 2. data performans reproduksi induk babi betina

\begin{tabular}{cccccc}
\hline $\begin{array}{c}\text { Periode } \\
\text { Beranak }\end{array}$ & $\begin{array}{c}\text { Jumlah In- } \\
\text { duk (ekor) }\end{array}$ & $\begin{array}{c}\text { Rata-Rata Lama } \\
\text { Estrus (hari) }\end{array}$ & $\begin{array}{c}\text { Siklus Estrus } \\
\text { (hari) }\end{array}$ & $\begin{array}{c}\text { Rata-rata liter } \\
\text { size (ekor) }\end{array}$ & $\begin{array}{c}\text { Rata-rata } \\
\text { Mortalitas }\end{array}$ \\
\hline 1 & 35 & $3,77 \pm 1,33^{\text {ab }}$ & $21,83 \pm 8,71^{\text {a }}$ & $8,14 \pm 2,75^{\text {a }}$ & $3,97 \pm 0,89^{\mathrm{a}}$ \\
2 & 44 & $3,91 \pm 1,36^{\text {ab }}$ & $19,96 \pm 2,07^{\mathrm{a}}$ & $8,18 \pm 2,82^{\mathrm{a}}$ & $4,14 \pm 0,88^{\mathrm{a}}$ \\
3 & 12 & $4,04 \pm 1,58^{\mathrm{a}}$ & $22,22 \pm 2,01^{\mathrm{a}}$ & $8,48 \pm 2,29^{\mathrm{a}}$ & $3,59 \pm 0,93^{\mathrm{a}}$ \\
4 & 25 & $3,64 \pm 1,18^{\mathrm{ab}}$ & $19,82 \pm 3,05^{\mathrm{a}}$ & $7,85 \pm 2,88^{\mathrm{a}}$ & $3,85 \pm 0,99^{\mathrm{a}}$ \\
5 & 34 & $3,29 \pm 0,99^{\mathrm{b}}$ & $20,84 \pm 1,87^{\mathrm{a}}$ & $8,12 \pm 2,78^{\mathrm{a}}$ & $4,26 \pm 1,06^{\mathrm{a}}$ \\
\hline Total & 196 & $3,67 \pm 1,28$ & $20,81 \pm 4,27$ & $8,13 \pm 2,72^{\mathrm{a}}$ & $4,01 \pm 0,97$ \\
\hline
\end{tabular}

Superskrip dengan huruf yang berbeda pada kolom yang sama menunjukkan pengaruh yang nyata $(\mathrm{P}<0,05)$

Tabel 2. Menggambarkan bahwa hasil survey dari 196 ekor induk dengan periode beranak yang berbeda menunjukkan bahwa rata-rata lama estrus mencapai $3,67 \pm 1,28$ hari, siklus estrus rata-rata

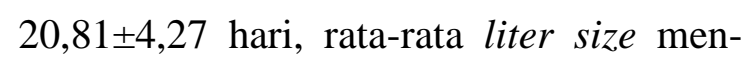
capai $8,13 \pm 2,72$ ekor dan mortalitas mencapai $39,71 \%$. Hasil analisis statistik menunjukkan bahwa lama estrus berpengaruh nyata $(\mathrm{P}<0,05)$ terhadap induk babi paritas 3 dan 5. Namun paritas 1, 2 dan 4 tidak menunjukkan pengaruh yang nyata ( $>0$,05). Disamping itu, paritas masingmasing induk babi tidak berpengaruh nyata $(\mathrm{P}>0,05)$ terhadap siklus estrus, litter size dan mortalitas. Hal ini di duga bahwa induk pada masa paritas 1 sampai 5 dalam tahap produktif. Meskipun demikian, performans reproduksi induk babi dipengaruhi oleh beberapa faktor antara lainnya yaitu faktor genetik (bangsa), umur, musim, makanan dan lingkungan.

\section{Lama estrus dan siklus estrus}

Estrus adalah kondisi fisiologis ternak yang siap melakukan perkawinan dalam waktu tertentu. Hasil penelitian menunjukkan bahwa $100 \%$ responden mampu mengamati tanda-tanda estrus pada induk babi yang dipelihara secara intensif. Dengan adanya keterampilan tersebut, biasanya peternak berusaha mengawinkan 
ternaknya dengan cara meminjam pejantan atau menyewa pejantan milik peternak lainnya. Kemampuan peternak dalam mendeteksi estrus dibuktikan dengan informasi tentang munculnya estrus pertama kali pada ternak babi di lokasi penelitian. Adapun tanda-tanda estrus pada induk betina antara lain: gelisah, napsu makan menurun, vulvanya membengkak dan berlendir serta vulva terlihat merah muda, diam bila punggunya di pegang dan sering menggigit kandang serta mengeluarkan suara nyaring (teriak) yang tidak seperti biasanya. Tandatanda estrus tersebut hampir sama seperti yang dilaporkan oleh peneliti terdahulu yakni (Toelihere, 1993); (Feradis, 2010) dan (Sumardani dan Andika, 2015).

Meskipun demikian, hasil wawancara terhadap peternak babi di Kelurahan Kambajawa menunjukkan bahwa rata-rata induk babi yang estrus dikawinkan pada 1-5 periode siklus estrus. Kondisi ini disebabkan karena keterbatasan pejantan baik sebagai sistem perkawinan alami maupun inseminasi buatan yang pada akhirnya populasi ternak babi menurun. Data Statistik Pertanian Sumba Timur dalam angka (2015), bahwa dalam rentan waktu 3 tahun berturut-turut populasi ternak babi di Sumba Timur terjadi penurunan dengan pertumbuhan per tahun hanya $1,37 \%$. Sedangkan populasi ternak babi pada tahun 2013 di capai (100.949 ekor); tahun 2014 (97.933) dan tahun 2015 (99.272 ekor).

Lama estrus merupakan salah satu indikator performans reproduksi induk babi yang dihitung dari waktu awal munculnya estrus hingga berakhirnya estrus. Hasil penelitian diperoleh lama estrus pada ternak babi rata-rata di capai pada 3,67 $\pm 1,28$ hari dengan kisaran 3,29 $\pm 0,99$ sampai dengan $4,04 \pm 1,58$ hari. Hasil ini sedikit berbeda seperti yang dilaporkan oleh beberapa peneliti terdahulu antara lain (Frandson, 1993), lama estrus pada babi mencapai 1-5 hari dengan rata-rata 2 hari. Sedangkan Toelihere (2002) dan Feradis (2010) yakni 2-3 hari. Adanya perbedaan ini diduga karena perbedaan umur ternak, lingkungan ternak, teknik pengamatan oleh peternak, jumlah kepemilikan ternak serta pengetahuan peternak dalam mengamati tingkah laku maupun tanda estrus.

Secara umum siklus estrus pada ternak babi merupakan interval waktu, pada permulaan periode estrus yang pertama sampai periode estrus berikutnya. Siklus estrus terdiri dari proestrus, estrus, metestrus dan diestrus. Lama siklus estrus pada babi berkisar 18-24 hari dengan rata-rata 21 hari dan panjang estrus 1-5 hari dengan rata-rata 2 hari (Frandson, 1993).

Hasil penelitian menunjukkan bahwa rata-rata siklus estrus pada babi dikelurahan Kambajawa mencapai 20,81 $\pm 4,27$ hari dengan kisaran 19,82 $\pm 3,05$ sampai dengan 22,22 $\pm 2,01$ hari. Hasil ini tergolong lebih lama jika dibandingkan dengan penelitian Sumardani dan Andika (2015), rata-rata siklus estrus dicapai 16,65 hari. Namun hasil penelitian ini hampir sama seperti yang dilaporkan Toelihere (1993) dan Feradis (2010), yakni siklus estrus rata-rata 20 hari meskipun kisaran berbeda yakni siklus estrus mencapai 18-22 hari. Adanya variasi siklus estrus disebabkan karena perbedaan individu ternak betina, bangsa ternak, umur, hormon, musim, pakan serta lingkungan. Hal ini di dukung penelitian (Hafez dan Hafez 2000; Morel 2002; England 2004 dan Malinowski 2008) bahwa siklus estrus dapat berbeda antara individu ternak betina.

\section{Liter size dan mortalitas}

Liter size merupakan salah satu indikator dalam mengukur produktivitas seekor induk babi ditentukan oleh jumlah anak yang lahir per induk babi dalam rentan waktu setahun. Menurut (Ardana dan Putra, 
2008), bahwa makin tinggi litter size dan farrowing rate (angka melahirkan anak) dari seekor induk, dapat diharapkan makin tinggi pula produktivitasnya dalam setahun atau selama umur reproduksi induk tersebut. Rata-rata liter size yang diperoleh pada lokasi penelitian ini mencapai 8,50 $\pm 1,39$ ekor. Hasil penelitian ini tergolong tinggi jika dibandingkan hasil hasil penelitian Tiro (2004), melaporkan bahwa rataan jumlah anak disapih adalah 6,8 dan 5,7 ekor masing-masing untuk Kecamatan Wamena dan Kecamatan Hubikosi. Demikian juga penelitian yang dilaporkan Sumardani dan Andika (2015), bahwa rata-rata liter size yakni 6,98 ekor. Namun, tiga penelitian lain litter size tergolong tinggi seperti laporan Toelihere (1993); Sihombing (2006) dan Feradis (2010), mengemukakan bahwa liter size 10-14 ekor/kelahiran. Penelitian dan Prasetyo, et al (2013), melaporkan hal yang sama bahwa liter sise mencapai 11,6 ekor/kelahiran. Sedangkan Sihombing (2006) litter size pada sekelahiran adalah 612 ekor anak babi.

Meskipun demikian, angka mortalitas dalam penelitian ini tergolong tinggi yakni $39,71 \%$ dengan kisaran $18,18 \%$ sampai dengan $55,55 \%$. Tingginya angka mortalitas ini dipengaruhi oleh manajemen pemeliharaan yang masih tradisional oleh peternak terutama pada ternak yang penyapihan dilakukan sendiri oleh ternak sendiri tanpa memperhatikan kualitas dan kuantitas pakan yang yang diberikan sehingga peternak umumnya tidak memperhatikan kematian yang ditimbulkan baik karena penyakit maupun lingkungan. Berdasarkan hasil wawancara membuktikan bahwa penyebab utama kematian anak babi adalah penyakit (diare), terhimpit atau tertindih induknya sendiri dan induk yang mengalami sakit serta kurangnya perhatian peternak pada ternak yang dipelihara terutama yang kepemilikan ternak 2-3 ekor.
Hasil penelitian ini diketahui bahwa angka mortalitas tergolong tinggi jika di bandingkan dengan hasil penelitian (Aku, et., al 2013 dan Prasetyo, et., al 2013) yakni mortalitas mencapai $20,69 \%$ dan 33,6\%, namun hasil penelitian terhadap angka mortalitas ini lebih rendah dari hasil penelitianpenelitian lainya diberbagai daerah. Wea (2016), melaporkan bahwa mortalitas terbesar pada babi lokal di Kodya Kupang terjadi pada fase pre weaning $62,07 \%$. Mortalitas yang tinggi pada fase pre weaning ini juga terjadi pada Kecamatan Wamena dan Kecamatan Hubikosi Kabupaten Jayawijaya yakni masing-masing $76,9 \%$ yang disebabkan karena terhimpit induk dan 90,7\% disebabkan karena terhimpit induk, diare dan penyakit pneumonia (Tiro, 2004).

Penyebab lain tingginya angka mortalitas pada anak babi, terjadi karena beberapa faktor antara lain abortus, kekurangan nutrisi dan terjepit induk serta penyakit (Sihombing, 2006). Lebih lanjut dikatakan bahwa sekitar 20 - 25\% dari anak babi yang lahir mati sebelum disapih dan sekitar $12 \%$ anak babi mati disebabkan tertindih atau terjepit induk dan $10-15 \%$ disebabkan penyakit.

\section{KESIMPULAN}

Berdasarkan hasil penelitian dapat disimpulkan bahwa rata-rata perfomans reproduksi induk babi di Kelurahan Kambajawa tergolong dalam kategori baik dengan beberapa indikator performans reproduksi induk yakni lama estrus induk babi mencapai 3,67 $\pm 1,28$ hari, siklus estrus rata-rata $20,81 \pm 4,27$ hari, rata-rata liter size mencapai $8,13 \pm 2,72$ ekor dan mortalitas mencapai $39,71 \%$. Sedangkan paritas ke tiga lama estrus cenderung lebih lama yakni $(4,04 \pm 1,58$ hari) dibandingkan dengan paritas ke lima dicapai pada 3,29 $\pm 0,99$ hari. 


\section{DAFTAR PUSTAKA}

Aritonang, D. dan M. Silalahi. (1999). Produktivitas Berbagai Galur Babi Ras Impor Selama Periode Laktasi. Jurnal ilmu ternak dan veteriner. Vol. 6. No. 1.

Ardana, I.B. dan, D.K.H. Putra. (2008). Ternak Babi (Manajemen Reproduksi, Produksi dan Penyakit). Udayana University Press.

Aku, A.S, T. Saili dan Amiruddin, (2013). Sebaran, Struktur Populasi dan Kinerja Reproduksi Babi Lokal di Kecamatan Tinanggea Kabupaten Konawe Selatan. Agriplus, Volume 23 Nomor: 03 September 2013.

Badan Pusat Statistik Sumba Timur, (2015). Statistik Pertanian Kabupaten Sumba Timur dalam angka 2015. Waingapu-Sumba Timur - NTT

Frandson, R.D. (1993). Anatomi dan Fisiologi Ternak. Gadjah Mada University Press. Yogyakarta.

Feradis. (2010). Reproduksi Ternak. Alfabeta. Bandung.

Geisert, R.D and R.A.M, Schmitt. (2002). Early Embryonic Survival In The Pig: Can It Be Improved. J. Anim. Sci. 80 :54- 85.

Hafez B. and Hafez E.S.E. (2000). Reproductive Behavior. In: Hafez ESE, Hafez B, editor. Reproduction in farm Animals.7th Ed. USA: Williams \& Wilkins.
Kojo, R.E, Panelewen V.V.J, Manase M.A.V, Santa N. (2014). Efisiensi Penggunaan Input Pakan dan Keuntungan pada Usaha Ternak Babi di Kecamatan Tateran Kabupaten Minahasa Selatan. Fakultas Peternakan Universitas Sam Ratulangi Manado. Jurnal Zootek ("Zootek" Journal) Vol 34(1): 62-74.

Lestari, S. K. (2000). Analisis investasi usaha tani ternak sapi potong yang tergabung dalam kandang kelompok. Skripsi. Fakultas Peternakan. Universitas Gadjah Mada. Yogyakarta.

Malinowski, K. (2008). Recent advances in reproduction in horse. Rutgers Cooperative Extension, The State University of New Jersey.

Mege R, Nasution S.H, Manalu W. March (2007). Pertumbuhan dan Perkembangan Uterus dan Plasenta Babi dengan Superovulasi. Hayati Journal of Biosciences. Vol. 14, No 1.

Morel, M. C. G. D. (2002). Equine Reproductive Physiology, Breeding and Stud Management. 2nd Edition. Institute of Rural Studies, University of Wales, Aberystwyth, UK.

Prasetyo, H., I.B.K. Ardana dan M.K. Budiasa. (2013). Studi Penampilan Reproduksi (Litter Size, Jumlah Sapih, Kematian) Induk Babi pada Peternakan Himalaya, Kupang. Jurnal Indonesia Medicus Veteriner 2 (3): 261-268.

Pardosi, U. (2004). Pengaruh Perkawinan Antara Tiga Bangsa Babi Terhadap Prestasi Anakdari Lahir Sampai Dengan Sapih Di PT. 
Mabarindo Sumpul Multiform.Tesis. Fakultas Peternakan Universitas Diponegoro.

Sapanca, P.L.Y; Wayan, I.C dan Made, I.S. (2015). Peningkatan Manajemen KelompokTernak Babi di Kabupaten Bangli.Agrimeta Vol. 15 No. 09: 1-69.

Sihombing. (2006). Ilmu Ternak Babi. Gadjah Mada University Press. Yogyakarta.

Sondang dan P. Siagian, (1999). Manajemen Sumber Daya Manusia, Bumi Aksara. Jakarta

Sihombing, D.T.H. (2006) Ilmu Ternak Babi. Ed.2. Gadjah Mada University Press. Bulaksumur, Yogyakarta.

Sumardani, N.L.G dan Ardika, I.N. (2015). Populasi dan Performans Reproduksi Babi Bali Betina di Kabupaten Karangasem Sebagai Plasma Nutfah Asli Bali. Seminar Nasional Sains dan Teknologi (Senastek-2015) Kuta, Bali, Indonesia, 29 - 30 Oktober 2015.

Seseray, D.Y.S., S. Triatmojo dan A. Pertiwiningrum. (2012). Pemanfaatan Feses Babi (Sus sp.) sebagai Sumber Gas Bio dengan Penambahan Ampas Sagu (Metroxylon spp.) pada Taraf Rasio C/N Ratio. Buletin Peternakan 36 (3): 66-74.

Toelihere M.R. (1993). Inseminasi Buatan pada Ternak. Angkasa. Bandung.

Tiro, B. M. W. (2004). Profil Peternakan Babi Pada Dua Kecamatan Di
Kabupaten Jayawijaya. Tesis. Program Pasca Sarjana Universitas Gadjah Mada Yogyakarta.

Utomo, S. dan V. Wahyuningsih. (2010). Dosis Campuran Limbah Sapi dengan Limbah Babi terhadap Produksi Gasbio. Jurnal AgriSains 1 (8): 7-14.

Wea, R. (2016). Performans Produksi dan Reproduksi Ternak Babi Lokal Di Kodya Kupang. Partner, Tahun 2016 Nomor 1 halaman 21-28. 